\title{
Erratum to: "Endophytic Bacteria in Microbial Preparations that Improve Plant Development (Review)" [Applied Biochemistry and Microbiology 51, 271 (2015)]
}

\author{
V. K. Chebotar ${ }^{a, b}$, N. V. Malfanova ${ }^{a, c}$, A. V. Shcherbakov ${ }^{a, b}$, G. A. Ahtemova ${ }^{a}$, A. Y. Borisov ${ }^{a}$, \\ B. Lugtenberg ${ }^{c}$, and I. A. Tikhonovich ${ }^{a}$ \\ ${ }^{a}$ All_Russia Research Institute for Agricultural Microbiology, Pushkin, 196608 Russia \\ ${ }^{b}$ International Research Center "Biotechnology of Third Millennium," Saint Petersburg National Research University \\ of Information Technologies, Mechanics and Optics (ITMO University), St. Petersburg, 191002 Russia \\ ${ }^{c}$ Institute of Biology, Leiden University, Leiden 2333, BE 8 Netherlands \\ e_mail:vladchebotar@rambler.ru \\ Submitted August 5, 2015; accepted for publication August 5, 2015
}

DOI: $10.1134 / \mathrm{S} 0003683815060174$

ACKNOWLEGMENTS should read as follows:

This work (sections "Biodiversity of endophytic bacteria, artificial inoculation of plants with endophytic bacteria and colonization of plant endosphere, influence of bacterial endophytes on plant growth and development, the ability of endophytic bacteria to control the development of plant diseases ("biocontrol activity"), endophytic bacteria - producers of "secondary metabolites") was supported by the Russian Science Foundation (project no. 14-16-00146), section "Prospects for the use of endophytic bacteria in microbial preparations that improve plant growth" with the financial support of the leading universities of the Russian Federation (grant 074-U01)". 